\title{
Brand awareness of Crisp!! Enye-Enye
}

\author{
M. Astuti \& M. Khoerunisa \\ Pembangunan Nasional Veteran Jakarta University, Indonesia
}

\begin{abstract}
This research is motivated by the low brand awareness of Crisp!! Enye-Enye, as it was ranked 11th out of 14 popular cassava-processed product brands in Banten Province in 2018. Therefore, this research aims at evaluating the effect of advertising, direct marketing, and personal selling on brand awareness. A quantitative descriptive research design was employed with 80 Crisp!! Enye-Enye consumers in different regions as the respondents. The research data analysis was conducted with the assistance of smartPLS version 3.2.7. The research results revealed that advertising, direct marketing, and personal selling had quite a high effect on brand awareness, with the R-squared value of $74.1 \%$. One of the three hypotheses was rejected; advertising and direct marketing were proven to affect brand awareness, while personal selling did not affect brand awareness.
\end{abstract}

\section{INTRODUCTION}

Micro, small, and medium enterprises (MSMEs) are very important for economic development in the community. Moreover, MSMEs have a strategic role in the national economic development. When the global economic crisis hit the world, MSMEs were still able to boost the national economy. Therefore, they contribute significantly to the gross domestic product (GDP) in Indonesia's economic growth (Sulistyo, 2020). Based on data from 2017 to 2019, MSMEs' contribution to Indonesia's GDP increased by $57.08 \%, 60 \%$, and $60.34 \%$ for three consecutive years.

According to the Department of Agriculture and Plantation of Lebak Regency (2019), the GRDP percentage in Lebak Regency fluctuated from 2015 to 2019. From 2015 to 2016, the value decreased by $10 \%$. Meanwhile, from 2017 to 2019 , the value increased by $10 \%, 5 \%$, and $4.9 \%$, respectively. This can occur because the management of potential and productivity in the area has not been optimized, even though it has a high potential related to superior food.

Foodstuffs are a promising source of culinary potential. One of the foodstuffs in Lebak Regency is cassava. With a harvest area of 2,539 hectares and a production level of 45,230 tons, cassava productivity is 17.81 tons/ha (Suryana, 2019). Meanwhile, the ideal cassava productivity is 20 60 tons/ha, so the cassava productivity in Lebak Regency has not reached the expected ideal figure (Ammurabi, 2019).

Research conducted by Astuti, Sembiring, and Amanda (2018) showed that Kelompok Wanita Pagoda (KWP/Pagoda Women's Group) in Lebak Regency produced enye-enye, which is a readyto-eat snack from cassava under the brand name "Crisp!! Enye-Enye". Even though the product marketing distribution covers three areas, namely, DKI Jakarta Province, Lebak Regency, and Tangerang Regency, the brand is not yet known by the public. The lack of understanding of the marketing strategies and knowledge in using social media is MSMEs' weakness (Mardiatmi and Pinem, 2016).

Based on the popularity of cassava-processed product brands in Banten Province, Crisp!! EnyeEnye was ranked 11th out of 14 in 2019. This indicates that the brand awareness was still low. The concept of a brand is not only for products from large-scale or multi-national companies. An MSME must also have a brand to encourage business progress and development (Lingga, 2019). 


\section{RESEARCH METHODOLOGY}

This research employed a descriptive quantitative research design. The population in this research was Crisp!! Enye-Enye consumers from Lebak Regency, Tangerang Regency, and DKI Jakarta Province. The sampling technique used was probability sampling with a random sampling design. 80 respondents were involved. The data were collected using primary data sources, namely, questionnaires. The data analysis technique was a descriptive analysis approach through the interpretation of the value of cross loading and loading factors (output partial least squares) and inferential analysis to test the hypothesis with the assistance of SmartPLS version 3.2.7 software.

\section{RESULT AND DISCUSSION}

\subsection{Descriptive analysis}

Based on the results of the analysis using SmartPLS version 3.2.7, the output factor loading and cross-loading for the variables used in the research are presented in Table 1.

Table 1. Descriptive analysis results.

\begin{tabular}{|c|c|c|}
\hline & Cross Loading & Loading Factor \\
\hline Variables & Average & Average \\
\hline $\begin{array}{l}\text { Brand awareness (Y) } \\
\text { Crisp!! Enye-Enye is the first product that I remember when } \\
\text { I remember snack foods made from cassava (High) } \\
\text { I know Crisp!! Enye-Enye products (Low) }\end{array}$ & 0.705 & \\
\hline $\begin{array}{l}\text { Advertising }\left(\mathbf{X}_{1}\right) \\
\text { The concept of the advertisement displayed makes me curious (High) } \\
\text { The advertising slogan is catchy to remember (Low) }\end{array}$ & & 0.760 \\
\hline $\begin{array}{l}\text { Direct Marketing }\left(\mathbf{X}_{2}\right) \\
\text { I can find advertising via social media (WhatsApp) (High) } \\
\text { The seller can provide detailed information about the product (Low) }\end{array}$ & & 0.766 \\
\hline $\begin{array}{l}\text { Personal Selling }\left(\mathbf{X}_{3}\right) \\
\text { Sellers ask for reviews after purchase (High) } \\
\text { Sellers maintain good relationships with consumers (Low) }\end{array}$ & & 0.754 \\
\hline
\end{tabular}

Source: Data Processed, 2020

Table 1 shows that the average cross-loading of brand awareness is 0.705 , which infers that the consumers realize that product promotion in various media helps the products to be easily recognized, so that this can help increase Crisp!! Enye-Enye's visibility. The average loading factor for advertising is 0.760 , which means that the consumers believe that advertising in the form of images, brand ambassadors, and slogans can attract consumers to remember the Crisp!! Enye-Enye brand. The average loading factor for direct marketing is 0.766 , which infers that the consumers think that direct marketing through social media, telephone, or face-to-face can give a good impression to consumers. The sellers can provide a detailed explanation of the product and respond to questions asked by consumers quickly. Furthermore, the average loading factor for personal sales is 0.754 , which indicates that in addition to direct advertising and marketing, the consumers also think that personal sales can raise consumer interest in the Crisp!! Enye-Enye products. In conclusion, the process of approaching, presentation and demonstration, overcoming objections, closing transactions, and follow-up had been done well. 


\subsection{Inferential analysis}

R-squared was used to measure the extent of the model's ability to explain variations in the dependent variable (Ghozali, 2016, p. 97). The output of SmartPLS is presented in Table 2.

Table 2. Value of R-squared.

\begin{tabular}{ll}
\hline & R-squared \\
\hline Brand Awareness & 0.741 \\
\hline
\end{tabular}

Source: SmartPLS Output

Table 2 shows that the independent variables of advertising, direct marketing, and personal selling are able to increase brand awareness by $74.1 \%$.

The $t_{!^{\prime \prime} \# \$} \%$ value in this research is 1.992 with a degree of error of 5\%. The results of data processing for significance testing (t-test) obtained are presented in Table 3.

Table 3. T-statistical test results.

\begin{tabular}{llll}
\hline & $\begin{array}{l}\text { Original } \\
\text { Sample }(\mathrm{O})\end{array}$ & $\begin{array}{l}\text { T Statistic } \\
(|\mathrm{O} / \mathrm{STDEV}|)\end{array}$ & P-Values \\
\hline Advertising-Brand awareness & 0.351 & 2.456 & 0.014 \\
Direct marketing-Brand awareness & 0.416 & 2.682 & 0.008 \\
Personal selling-Brand awareness & 0.174 & 0.962 & 0.336 \\
\hline
\end{tabular}

Source: SmartPLS Output

The results of hypothesis testing show that advertising positively and significantly affects brand awareness with a path coefficient value of 0.351 . In other words, if advertising decreases in terms of quality of the product concept and appearance, then brand awareness also decreases. The indicators used in advertising include drawing attention, attractive appearance, and increase of desire and action that can increase the Crisp!! Enye-Enye brand awareness. The results are also in line with the research studies conducted by Dewi and Sugandi (2019), Putri et al. (2019), and Septiningrum and Sudrajat (2019), who stated that advertising can increase brand awareness.

In addition, direct marketing positively and significantly affected brand awareness with a path coefficient value of 0.416 , which indicates that when direct marketing increases by one unit, brand awareness also increases by 0.416 . The results are supported by Shintarani (2017).

Furthermore, personal selling has no significant effect, but has a positive direction on brand awareness with a path coefficient of 0.174 , which indicates that personal sales do not affect the Crisp!! Enye-Enye brand awareness. The results are not in line with the research conducted by Dewi and Magdalena (2017) and Shintarani (2018), who state that personal selling can increase brand awareness.

The difference in the research results could be affected by different research objects. Previous research used more large-scale company objects, while in this research, MSMEs with unknown product results were used as the research object. In addition, the criteria for sampling were different. The research conducted by Shintarani (2017) concluded that personal sales in companies were carried out by sales professionals. Meanwhile, at the Crisp!! Enye-Enye as one of MSMEs, the marketing was still lacking in terms of good marketing strategy practices. The follow-up and maintenance are needed to be carried out in personal sales in order to ensure customer satisfaction and repeat customers (Kotler \& Armstrong, 2016). Meanwhile, The Crisp!! Enye-Enye sellers do not follow up, such as asking for reviews and maintaining good relationships with consumers. 


\section{CONCLUSION}

This research concluded that advertising increased the Crisp!! Enye-Enye brand awareness. Furthermore, direct marketing also increased the Crisp!! Enye-Enye brand awareness. However, personal sales neither increased nor decreased the Crisp!! Enye-Enye brand awareness.

\section{REFERENCES}

Ammurabi, S. D. (2019, December 2). Tekan Impor Gandum, MSI Usul Pengembangan 1 Juta Ha Singkong. Gatra. https://www.gatra.com/detail/news/459799/ekonomi/tekan-imporgandum-msi-usulpengembangan-1-juta-ha-singkong.

Astuti, M., Sembiring, R., \& Amanda, A. R. (2018). Program Kemitraan Komunitas pada 'EnyeEnye' di Desa Mekar Agung, Kabupaten Cibadak, Lebak - Banten. Kumawula: Jurnal Pengabdian Kepada Masyarakat, 1(3), 131-149. doi:10.24198/kumawula.v1i3.19196.

Dewi, L. \& Magdalena, F. (2017). Pengaruh Personal Selling Dan Word Of Mouth Terhadap Brand Awareness Bisnis Mahasiswa Universitas Ciputra. Jurnal Eksekutif, 14(2), 253261.

Dewi, Y. L. and Sugandi, M. S. (2019). Pengaruh Iklan Web Series SPace \# “Kenapa Belum Nikah?” Terhadap Brand Awareness JD.ID. Profetik: Jurnal Komunikasi, 12(1), 141-148. doi:10.14421/pjk.v12i1.1556.

Kotler, P., \& Armstrong, G. (2016). Principles of Marketing Global Edition (Sixteenth). Harlow: Pearson.

Lingga, M. A. (2019, February 26). Meski Produk UMKM, Ternyata Sangat Penting Miliki Brand dan Hak Cipta. Kompas. https://ekonomi.kompas.com/read/2019/02/26/174108026/meski-produk-umkmternyatasangat-penting-miliki-brand-dan-hak-cipta.

Mardiatmi, B. D., \& Pinem, D. (2016). The Study on the Marketing Mix Development Strategy Analysis of Creative Industry Sme-Based in Depok West Java. International Journal of Business \& Commerce, 5(6), 91-104.

Putri, A. N., Handayani, T., \& Astuti, M. (2019). Pengaruh iklan, Selebriti Pendukung dan Pemasaran dari Mulut ke Mulut Terhadap Kesadaran Merek pada Produk Mie Sedaap. Jurnal Manajemen, 11(1), 24-34. doi:10.29264/jmmn.v11i1.4524.

Septiningrum, W., \& Sudrajat, R. H. (2019). Pengaruh Jingle Iklan Susu Koperasi Peternakan Bandung Selatan Pengalengan Terhadap Brand Awareness. e-Proceeding of Management, 6(2), pp. 5107-5117.

Shintarani, E. D. (2018). Pengaruh Promosi Produk Seafoodking terhadap Brand Awareness Produk. Nyimak (Journal of Communication), 1(2), pp. 209-220. doi:10.31000/nyimak.v1i2.484.

Sulistyo, C. B. (2020, January 4) Pemberdayaan UMKM Menuju Go International. Investor Daily. https://investor.id/opinion/pemberdayaan-umkm-menuju-go-international.

Suryana, M. (2019, November 23) Produksi ubi kayu di Lebak tembus 45.230 ton dengan luas tanam 2.539 hektare. Antara News Biro Banten. https://banten.antaranews.com/berita/74984/produksi-ubi-kayudi-lebak-tembus-45230ton-dengan-luas-tanam-2539-hektare 